\title{
Five-year Term Evaluation of the Project Named "Kilis Goat National Breeding Project in Kilis Province"
}

\author{
Mahmut Keskin ${ }^{1, *}\left(\mathbb{D}\right.$, Sabri Gül ${ }^{1}\left(\mathbb{D}\right.$, Şerafettin Kaya ${ }^{1} \mathbb{( D}$ \\ ${ }^{1}$ Hatay Mustafa Kemal University, Agriculture Faculty, Department of Animal Sciences, Hatay, Türkiye \\ *Corresponding Author
}

\section{Article History}

Received: 19 November 2021 Accepted: 20 December 2021 First Online: 01 April 2022

\section{Corresponding Author* \\ Tel.: +90 5333922874 \\ E-mail:mkeskin@mku.edu.tr}

\section{Keywords}

Birth weight

Weaning weight

Milk yield

\begin{abstract}
Kilis Goat National Breeding Project has been carried out for 12 years in cooperation with The General Directorate of Agricultural Research and Policies in the Ministry of Agriculture and Forestry, Hatay Mustafa Kemal University and Sheep and Goat Breeders Association of Kilis Province. The aim of the manuscript is to inform about progresses made under the relevant project. In the second five-year period of the project, 43 breeders take part in a total of approximately 6000 female and 300 male animals. Thirtyseven of these herds are base herds and six of them are elite herds. In the study, the effects of gender, maternal age, separation as breeding stock or not, birth types and years on birth and weaning weights were analysed by using the SPSS package program. The effects of herd and age differences on lactation milk yield in elite herds were also analysed by using the SPSS package program. They were determined that birth weights varied between 2.9-3.1 kg and weaning weights between 11.2-12.7 kg for different years. And, milk yield in elite herds increased from $175.6 \mathrm{~kg}$ to $346.1 \mathrm{~kg}$ from 2016 to 2020 . As conclusion, it is recommended that the continuation of this project will be beneficial.
\end{abstract}

\section{Introduction}

Türkiye is among the countries that could be faced with the problem of drought in the future due to global climate change. Therefore, starting from today, it is necessary to develop appropriate livestock strategies and make future plans for better nutrition of the increasing human population. In this context, there is a great benefit in planning what the share of sheep, goats, cattle and buffalo will be in Türkiye's livestock, and which species and even breeds will be raised in which region.

Goat is an important material to meet the animal protein needs of the society. Goat is one of the animal species that has proportionally the most increment in the last 30 years in the World (www.fao.org). Undoubtedly, the fact that the goat will be among the advantageous species in the future due to global climate change and the characteristics of goat milk have effects on this increase.
Türkiye goat population, which was around 16 million at the beginning of the 1980s, is around 12 million today, and $97 \%$ of it is Hair goat (www.tuik.gov.tr). Hair goats are kept with extensive system in many regions of Türkiye. These goats, which have hard hooves and the ability to walk long, are extremely resistant to adverse environmental conditions. Milk yield for these goats has been reported as between 87 and $146 \mathrm{~kg}$, and litter size as between $65 \%$ and $100 \%$ by different Researchers (Sönmez et al.,1973; Özcan et al., 1974; Sönmez, 1974; Şimşek et al., 2006).

Hair goats, which are kept with the extensive system completely dependent on nature in Türkiye, are preferred by the breeders as a profitable production tool despite their low yield characteristics. Unfortunately, a false anxiety is often expressed that forests are adversely affected in this production model. We know that hair goats, when managed correctly, provide benefits to forest 
without any harm. For example, they contribute to reducing the risk of fire by eating cover plants and maquis. However, with the effect of this wrong belief, it has been said for a long time to reduce the number of Hair goats but to increase the dairy genotypes in order to protect forests and to produce in accordance with European Union standards. In this context, in the Türkiye Livestock Projection study conducted in 1969, it was foreseen that the goat population will be gradually decreased in the country. In this projection study, it was also reported that the ratio of dairy genotypes in the country's goat population should be increased in the future. In the study, it was predicted that the number of goats in the year of 2000 would be 3.6 million heads and this number would consist of $25 \%$ Hair goat, $15 \%$ Kilis goat, 5\% Maltese goat and $55 \%$ dairy crossbreeds (Anonymous, 1969). For the purpose of obtaining this composition different crossbreeding studies have been started since the 1960s and have been carried out in different Universities in cooperation with the Ministry of Agriculture. For this aim some crossbred genotypes were obtained by using Saanen and Alpine bucks brought from different European countries in the breeding of Hair goat. Important results were obtained in this crossbreeding studies on milk yield, reproductive characteristics and kid developments (Özcan, 1977; Güney, 1984).

As mentioned in the projection study, Kilis goats are an important genetic material for goat breeding in Turkiye. Although not included in official figures, it is estimated that there are approximately 500 thousand heads of Kilis goats in the provinces of Kilis, Adana, Gaziantep and Hatay (Keskin et al., 2017). Kilis goat is numerically less than the Hair goat and draws attention with its high yield characteristics. Although the Kilis goat is often confused with the Damascus or Aleppo goat, it is a different genotype (Keskin et al., 1996; Keskin, 2000). Although this breed is reared in Kilis, Hatay, Gaziantep regions, it has been taken to many regions of Turkiye especially after this project and its keeping continues without any problems.

The National Animal Breeding Project conducted under the breeders' conditions has undertaken an important mission in terms of seeing the diversity of our genetic resources in the field of small ruminant breeding in Turkiye and improvement them on site. The existence of many sheep and goat breeds that are not included in the data of the Turkish Statistical Institute started to take place in the literature with this project. "National Genetic Improvement Project for Kilis Goats at Breeders' Condition" is one of the subprojects of this national project. This project has been carried out as two sub-projects in the province of Kilis. The results covering the period of 2016-2021 of the second package of the sub-project are included in this manuscript.

\section{Materials and Methods}

A total of 6300 goats, approximately 6000 female and 300 male goats from Kilis goat breed, and their kids constituted the animal material of the project. Individuals with black colour and long ears are preferred in the selection of breeding stocks in the project in addition to milk yield, kid development and reproduction characteristics. An index that takes into account kids' birth and weaning weights, their mothers' milk yield gave during two milk control in March - May period as well as birth type was used in the breeding separation of the kids.

$\mathrm{I}=0,10 \times \mathrm{BW}+0,30 \mathrm{xWW}+0,30 \mathrm{xFMY}+0,30 \mathrm{xSMY}+$ BT (I, index; BW, birth weight; WW, weaning weight, FMY, milk yield at first control; SMY, milk yield at second control; BT, birth type)

Mating in the base herds was carried out by free mating method in August-September every year, and the bucks were separated from the females at least 45 days before the mating date in the base herds for oestrus synchronisation. After that, bucks and does were kept together with proportion of 5 males for 100 females until the end of the mating period. In these herds, the kids were ear-tagged at birth, the ear tag numbers of the mother and the kid, the date of birth, the number of kids at the birth (type of birth) and the sex of the kids were recorded. Weighings of the kids were made at birth and on the 60th day to reveal the growth performance of the kids. Since free breeding was done in the base herds, mating records could not be obtained, only the mother and offspring information were recorded.

In elite herds, hand mating was applied and mating records of animals were kept. Ear tag numbers of the goats giving birth, numbers of kids at birth, date of birth as well as ear numbers, genders, birth and 60th day weights of born kids were recorded. Breeding stocks were selected from the born kids for each herd at each year as $40 \%$ of the females and all the males.

In order to calculate the lactation milk yields of the goats in the elite herds, milk controls were made at 28day intervals and individual milk yields were calculated with the ICAR-AT method, which was also used by Keskin et al. (Keskin et al., 2017).

The mathematical model used for the analysis of the data obtained in the project is given below.

$Y_{i j k l m n}=\mu+a_{i}+b_{j}+c_{k}+d_{1}+f_{m}+e_{i j k l m n}$; in this model;

YijkImn= The data (birth weight, weaning weight, lactation milk yield) of $n^{\text {th }}$ animal at $i^{\text {th }}$ herd (elite or base) group, $\mathrm{j}^{\text {th }}$ breeding stock separation or non- 
separation group, $\mathrm{k}^{\text {th }}$ maternal age, $\mathrm{I}^{\text {th }}$ gender and $\mathrm{m}^{\text {th }}$ birth type.

$$
\begin{aligned}
& \mu=\text { mean of population } \\
& a_{i}=\text { effect of herd group }(i=\text { elite or base }) \\
& b_{j}=\text { effect of breeding stock situation } \\
&(j= \text { separation on non-separation) } \\
& c_{k}=\text { effect of maternal age }(k=2,3,4,5,6,7+) \\
& d_{l}=\text { effect of gender }(l=\text { male or female) } \\
& f_{m}=\text { effect of birth type ( } m=\text { single or twin) } \\
& e_{i j k l m n}=\text { error factor }
\end{aligned}
$$

The data obtained in the study were analysed with the Oneway Anova procedure and the comparisons of the averages were made with the Duncan test by using SPSS Package Program.

\section{Results and Discussion}

The reproductive traits calculated from the project goats in the 5-year period between 2016-2020 are given in Table 1. When Table 1 is evaluated, it is seen that the birth rate determined from the project animals is lower than the $96 \%$ birth rate determined by Keskin et al. (1996). This may be due to the fact that the study of Keskin et al. (1996) was conducted in a single herd with a small number of animals and the animals were managed in better conditions.

Table 1. Some reproductive traits calculated in project material goats.

\begin{tabular}{ccccccc}
\hline Years & KR & KY1 & KY2 & KY3 & KY4 & SRW \\
\hline 2016 & 62.4 & 79.0 & 79.0 & 126.7 & 126.7 & 100.0 \\
2017 & 70.3 & 81.9 & 73.4 & 116.6 & 104.5 & 89.6 \\
2018 & 87.3 & 101.7 & 83.8 & 116.5 & 96.0 & 82.4 \\
2019 & 92.1 & 109.7 & 85.7 & 119.1 & 93.0 & 78.1 \\
2020 & 86.9 & 99.8 & 77.5 & 114.9 & 89.1 & 77.6 \\
\hline
\end{tabular}

$\mathrm{KR}$, kidding rate; $\mathrm{KY} 1$, kid yield at birth for goats at herd; $\mathrm{KY} 2$, kid yield at weaning for goats at herd; $\mathrm{KY} 3$, kid yield at birth for goats giving birth; $\mathrm{KY} 4$, kid yield at weaning for goats giving birth; SRW, survival rate at weaning

It is seen that the reproductive traits obtained in the present study change from year to year. These changes are a natural consequence of the effect of environmental conditions changing from year to year in herds managed under extensive or semi-intensive conditions. The variability observed in the fertility criteria, especially the decrease in "kid yield at weaning for goats giving birth and survival rate at weaning" values may also be affected by the variability observed in climatic conditions from year to year. According to the multi-year meteorological data, the lowest temperature values in Kilis province can vary between $-12{ }^{\circ} \mathrm{C}$ and $-5.6{ }^{\circ} \mathrm{C}$ in the January-March period (Anonymous, 2021), which is the period between birth and weaning for kids. In addition, cottonseed grains fed to animals during this period may also be effective in the deaths of kids during this period. We know that nowadays cotton is harvested by machine and chemicals are applied to the cotton plant before harvesting. It should be useful to investigate these issues. In the study conducted with Kilis goats reared in the same region (Keskin, 2000), the birth rate, kid yield at birth and survival rate at weaning were reported as $89.7 \%, 130 \%$ and $89.2 \%$ respectively. As stated in the study in question, there may be differences from year to year in terms of these characteristics.

The effects of being included in elite or base herds, separation status as breeding stocks, maternal age, gender, birth type on birth and weaning weights are given in Table 2, Table 3, Table 4, Table 5 and Table 6. As can be seen from these Tables, birth type, gender and maternal age had significant effects on both birth and weaning weights $(P<0.05)$. In addition, statistically significant differences were also determined between the animals selected or not selected as breeding stocks $(P<0.05)$. Birth and weaning weights has got $40 \%$ effect in the index formula to select the animals as breeding stocks. Kids with a high index value are selected as breeding stocks with this formula. For this reason, it can be considered as a normal situation for the animals selected as breeding stocks to be heavier than the others, especially during the weaning period.

Birth and weaning weights determined in the study were sometimes similar and sometimes different from the values reported in different studies. Thus, birth and weaning weights for Kilis goats have been reported as $3.8 \mathrm{~kg}$ and $18.6 \mathrm{~kg}$ (Aktepe, 2009), $3.6 \mathrm{~kg}$ and $12.3 \mathrm{~kg}$ (Keskin et al., 2017), respectively. These differences are influenced by environmental factors, especially feeding. That is, in the study conducted by Keskin (2020), the birth weight of Kilis goats, which were given additional feeding, was determined as $4.6 \mathrm{~kg}$ and weaning weight as $13.2 \mathrm{~kg}$. In other words, better feeding of animals can affect both birth and weaning weights. Therefore, environmental conditions that change from year to year have important effects on the variability of birth and weaning weights calculated for different years from herds reared in semi-intensive conditions during the project. When the effects of birth type and sex on the average birth and weaning weights at the herds are evaluated, single born kids were generally heavier than twins and 
Table 2. Effect of different factors on birth and weaning weight $(\bar{x} \pm s \bar{x})$ (year of 2016).

\begin{tabular}{|c|c|c|}
\hline & Birth weight & Weaning weight \\
\hline \multicolumn{3}{|c|}{ Elite-Base Herds } \\
\hline Elite & $3.0 \pm 0.02(1223)$ & $12.3 \pm 0.07^{a}(1157)$ \\
\hline Base & $3.0 \pm 0.01(3805)$ & $12.8 \pm 0.05^{\mathrm{b}}(3586)$ \\
\hline \multicolumn{3}{|c|}{ Selected or not selected as breeding stocks } \\
\hline Selected & $3.2 \pm 0.02^{b}(1592)$ & $14.4 \pm 0.08^{b}(1494)$ \\
\hline Not selected & $3.0 \pm 0.01^{\mathrm{a}}(3434)$ & $11.9 \pm 0.04^{\mathrm{a}}(3199)$ \\
\hline \multicolumn{3}{|l|}{ Maternal age } \\
\hline 2 & $3.1 \pm 0.02^{b}(1291)$ & $12.5 \pm 0.07^{\mathrm{ab}}(1183)$ \\
\hline 3 & $3.0 \pm 0.02^{\mathrm{a}}(1007)$ & $12.4 \pm 0.07^{\mathrm{a}}(953)$ \\
\hline 4 & $3.1 \pm 0.02^{\mathrm{ab}}(1303)$ & $12.6 \pm 0.10^{\mathrm{ab}}(1218)$ \\
\hline 5 & $3.1 \pm 0.04^{b}(452)$ & $13.0 \pm 0.12^{c}(431)$ \\
\hline 6 & $3.0 \pm 0.05^{a}(130)$ & $13.6 \pm 0.27^{d}(120)$ \\
\hline $7+$ & $3.1 \pm 0.03^{b}(845)$ & $12.9 \pm 0.10^{\mathrm{bc}}(788)$ \\
\hline \multicolumn{3}{|l|}{ Gender } \\
\hline Male & $3.1 \pm 0.01^{b}(2559)$ & $12.9 \pm 0.05^{\mathrm{b}}(2386)$ \\
\hline Female & $3.0 \pm 0.02^{\mathrm{a}}(2457)$ & $12.4 \pm 0.06^{\mathrm{a}}(2307)$ \\
\hline \multicolumn{3}{|l|}{ Birth type } \\
\hline Single & $3.2 \pm 0.77^{c}(2902)$ & $13.2 \pm 0.05^{b}(2683)$ \\
\hline Twin & $2.9 \pm 0.66^{b}(2054)$ & $12.2 \pm 0.07^{a}(1944)$ \\
\hline Triplet & $2.7 \pm 0.85^{\mathrm{a}}(72)$ & $12.4 \pm 0.33^{\mathrm{a}}(66)$ \\
\hline Total & $3.1 \pm 0.01(5026)$ & $12.7 \pm 0.04(4693)$ \\
\hline
\end{tabular}

Note: Different letters as superscripts in the same column indicate a difference at the $5 \%$ significance level.

triplets and male kids were generally heavier than female ones.

Similar reports were also stated by different researchers (Baltacı, 1990; Keskin et al., 2017; Keskin et al., 2019) that the birth weight for Kilis goats bred in the same region as $3.7 \mathrm{~kg}$ in single born kids, $3.5 \mathrm{~kg}$ in twin kids, $3.8 \mathrm{~kg}$ in male kids and $2.4 \mathrm{~kg}$ in female kids. The researchers reported the weaning weight for the same kids as $12.2 \mathrm{~kg}$ in single born kids, $12.1 \mathrm{~kg}$ in twin kids, $12.6 \mathrm{~kg}$ in male kids and $11.9 \mathrm{~kg}$ in female kids. These values are in line with the results reported in the present study. Likewise, Keskin et al. (2017) stated that the average values of these characteristics could change from year to year.
Kilis goat is one of the most important domestic goat gene sources of Türkiye in terms of milk yield. The primary aim of this project is to improve the milk yield of Kilis goats. As can be seen in Table 7, the average lactation milk yields of Kilis goats in the elite herds were calculated as $175.6 \pm 2.00 \mathrm{~kg}, 301.2 \pm 3.61$ $\mathrm{kg}, 316.5 \pm 2.36,310.8 \pm 2,02$ and $346.1 \pm 1.46 \mathrm{~kg}$ in the years of 2016 - 2020, respectively. As can be seen in Figure 1, the milk yields in the elite herds tend to increase from year to year, although there may be slight fluctuations.

Undoubtedly, although the changes in the environmental conditions to which the herds managed 
$\mathrm{Kg}$

Lactation milk yield

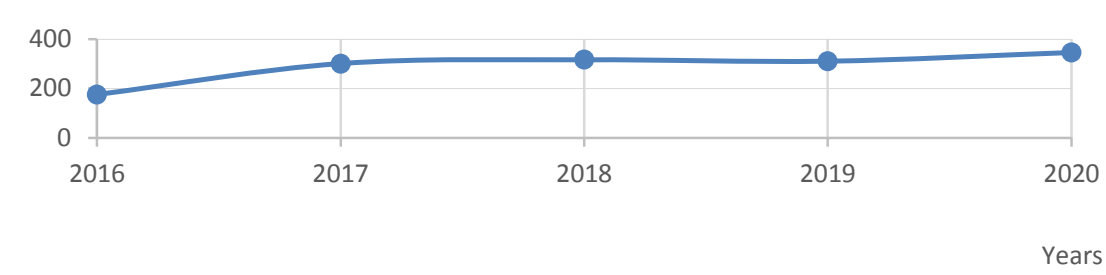

Figure 1. Variation of average lactation milk yield in the elite herds by years.

Table 3. Effect of different factors on birth and weaning weight $(\bar{x} \pm s \bar{x})$ (year of 2017).

\begin{tabular}{|c|c|c|}
\hline & Birth weight & Weaning weight \\
\hline \multicolumn{3}{|c|}{ Elite-Base Herds } \\
\hline Elite & $3.0 \pm 0.01(1145)$ & $12.2 \pm 0.07^{b}(860)$ \\
\hline Base & $3.0 \pm 0.01$ (3579) & $12.1 \pm 0.04^{\mathrm{a}}(3199)$ \\
\hline \multicolumn{3}{|c|}{ Selected or not selected as breeding stocks } \\
\hline Selected & $3.1 \pm 0.01^{b}(1368)$ & $13.5 \pm 0.05^{\mathrm{b}}(1311)$ \\
\hline Not selected & $3.0 \pm 0.01^{a}(3353)$ & $11.4 \pm 0.03^{\mathrm{a}}(2745)$ \\
\hline \multicolumn{3}{|l|}{ Maternal age } \\
\hline 2 & $3.1 \pm 0.01^{b}(942)$ & $12.3 \pm 0.07^{b}(1183)$ \\
\hline 3 & $3.1 \pm 0.01^{c}(1045)$ & $12.0 \pm 0.07^{\mathrm{ab}}(953)$ \\
\hline 4 & $3.0 \pm 0.01^{\mathrm{abc}}(944)$ & $11.9 \pm 0.07^{\mathrm{a}}(1218)$ \\
\hline 5 & $3.0 \pm 0.01 a^{b}(981)$ & $12.1 \pm 0.07^{\mathrm{ab}}(431)$ \\
\hline 6 & $3.0 \pm 0.02^{\mathrm{abc}}(345)$ & $12.3 \pm 0.12^{b}(120)$ \\
\hline $7+$ & $3.0 \pm 0.02^{\mathrm{a}}(467)$ & $11.9 \pm 0.10^{\mathrm{a}}(788)$ \\
\hline \multicolumn{3}{|l|}{ Gender } \\
\hline Male & $3.1 \pm 0.01^{b}(2559)$ & $12.4 \pm 0.04^{b}(2082)$ \\
\hline Female & $3.0 \pm 0.02^{\mathrm{a}}(2457)$ & $11.7 \pm 0.05^{\mathrm{a}}(1976)$ \\
\hline \multicolumn{3}{|l|}{ Birth type } \\
\hline Single & $3.1 \pm 0.01^{c}(2902)$ & $12.3 \pm 0.04^{b}(2901)$ \\
\hline Twin & $2.9 \pm 0.01^{b}(2054)$ & $11.6 \pm 0.06^{b}(1944)$ \\
\hline Triple & $2.8 \pm 0.05^{\mathrm{a}}(72)$ & $9.5 \pm 0.37^{a}(15)$ \\
\hline Total & $3.0 \pm 0.01(4724)$ & $12.1 \pm 0.03(4056)$ \\
\hline
\end{tabular}

Note: Different letters as superscripts in the same column indicate a difference at the $5 \%$ significance level. 
Livestock Studies 62(1), 7-15

Table 4. Effect of different factors on birth and weaning weight $(\bar{x} \pm s \bar{x})$ (year of 2018).

\begin{tabular}{|c|c|c|}
\hline & Birth weight & Weaning weight \\
\hline \multicolumn{3}{|c|}{ Elite-Base Herds } \\
\hline Elite & $3.0 \pm 0.02^{\mathrm{a}}(1407)$ & $11.9 \pm 0.06^{\mathrm{a}}(1333)$ \\
\hline Base & $3.1 \pm 0.01^{b}(4230)$ & $12.2 \pm 0.03^{b}(3513)$ \\
\hline \multicolumn{3}{|c|}{ Selected or not selected as breeding stocks } \\
\hline Selected & $3.1 \pm 0.02^{b}(947)$ & $14.4 \pm 0.05^{b}(947)$ \\
\hline Not selected & $3.0 \pm 0.01^{\mathrm{a}}(4686)$ & $11.5 \pm 0.03^{\mathrm{a}}(3695)$ \\
\hline \multicolumn{3}{|l|}{ Maternal age } \\
\hline 2 & $3.1 \pm 0.01^{\mathrm{ab}}(1224)$ & $12.1 \pm 0.07^{\mathrm{ab}}(975)$ \\
\hline 3 & $3.1 \pm 0.01^{\mathrm{ab}}(1913)$ & $12.1 \pm 0.05^{\mathrm{a}}(1587)$ \\
\hline 4 & $3.1 \pm 0.01^{b}(1158)$ & $12.2 \pm 0.06^{\mathrm{ab}}(974)$ \\
\hline 5 & $3.1 \pm 0.02^{\mathrm{ab}}(684)$ & $12.1 \pm 0.08^{\mathrm{c}}(573)$ \\
\hline 6 & $3.0 \pm 0.02^{\mathrm{a}}(422)$ & $12.2 \pm 0.10^{d}(361)$ \\
\hline $7+$ & $3.0 \pm 0,02^{a}(216)$ & $12.1 \pm 0.14^{b c}(176)$ \\
\hline \multicolumn{3}{|l|}{ Gender } \\
\hline Male & $3.1 \pm 0.01(2884)$ & $12.1 \pm 0.04(2448)$ \\
\hline Female & $3.0 \pm 0.01(2752)$ & $12.1 \pm 0.04(2197)$ \\
\hline \multicolumn{3}{|l|}{ Birth type } \\
\hline Single & $3.2 \pm 0.01^{b}(4600)$ & $12.6 \pm 0.04^{c}(3900)$ \\
\hline Twin & $3.1 \pm 0.02^{\text {ba }}(1022)$ & $12.2 \pm 0.07^{b}(736)$ \\
\hline Triple & $2.9 \pm 0.17^{a}(15)$ & $11.8 \pm 0.46^{\mathrm{a}}(10)$ \\
\hline Total & $3.1 \pm 0.01(5637)$ & $12.1 \pm 0.03(4646)$ \\
\hline
\end{tabular}

Note: Different letters as superscripts in the same column indicate a difference at the $5 \%$ significance level.

Table 5. Effect of different factors on birth and weaning weight ( $\bar{x} \pm s \bar{x})$ (year of 2019).

\begin{tabular}{lll}
\hline & Birth weight & Weaning weight \\
\hline Elite-Base Herds & & \\
\hline Elite & $2.9 \pm 0.01^{\mathrm{b}}(1419)$ & $11.3 \pm 0.05^{\mathrm{a}}(1054)$ \\
Base & $2.8 \pm 0.01^{\mathrm{a}}(4844)$ & $11.2 \pm 0.03^{\mathrm{b}}(3840)$ \\
\hline Selected or not selected as breeding stocks & \\
\hline Selected & $2.9 \pm 0.01^{\mathrm{b}}(1114)$ & $13.2 \pm 0.04^{\mathrm{b}}(914)$ \\
Not selected & $2.8 \pm 0.01^{\mathrm{a}}(5149)$ & $10.6 \pm 0.03^{\mathrm{a}}(3880)$ \\
\hline Maternal Age & & \\
\hline 2 & $2.9 \pm 0.01^{\mathrm{bc}}(1764)$ & $11.2 \pm 0.05^{\mathrm{b}}(1383)$ \\
\hline 3 & $2.9 \pm 0.01^{\mathrm{c}}(1099)$ & $11.2 \pm 0.06^{\mathrm{b}}(850)$ \\
\hline 4 & $2.9 \pm 0.01^{\mathrm{c}}(1692)$ & $11.3 \pm 0.05^{\mathrm{b}}(1288)$ \\
\hline 5 & $2.8 \pm 0.01^{\mathrm{ab}}(1075)$ & $11.2 \pm 0.06^{\mathrm{b}}(882)$ \\
\hline 6 & $2.8 \pm 0.01^{\mathrm{a}}(485)$ & $10.8 \pm 0.10^{\mathrm{a}}(384)$ \\
\hline $7+$ & $2.8 \pm 0.02^{\mathrm{ab}}(148)$ & $10.7 \pm 0.19^{\mathrm{a}}(107)$ \\
\hline Gender & & $11.4 \pm 0.04^{\mathrm{b}}(2461)$ \\
\hline Male & $2.9 \pm 0.01^{\mathrm{b}}(3081)$ & $10.9 \pm 0.03^{\mathrm{a}}(2433)$ \\
\hline Female & $2.8 \pm 0.01^{\mathrm{a}}(3182)$ & $11.2 \pm 0.03(4894)$ \\
\hline Birth type & $2.9 \pm 0.01^{(6263)}$ & $11.4 \pm 0.03^{\mathrm{b}}(3296)$ \\
\hline Single & $2.8 \pm 0.01^{\mathrm{a}}(2004)$ & - \\
\hline Twin & - & \\
\hline Triplet & & \\
\hline Total & & \\
\hline
\end{tabular}


Livestock Studies 62(1), 7-15

Table 6. Effect of different factors on birth and weaning weight $(\bar{x} \pm s \bar{x})$ (year of 2020).

\begin{tabular}{lll}
\hline & Birth weight & Weaning weight \\
\hline Elite-Base Herds & & \\
\hline Elite & $3.0 \pm 0.02^{\mathrm{b}}(1478)$ & $11.7 \pm 0.06^{\mathrm{b}}(1159)$ \\
Base & $2.9 \pm 0.01^{\mathrm{a}}(4390)$ & $11.2 \pm 0.03^{\mathrm{a}}(3395)$ \\
\hline Selected or not selected as breeding stocks & $13.7 \pm 0.05^{\mathrm{b}}(975)$ \\
\hline Selected & $3.2 \pm 0.02^{\mathrm{b}}(1000)$ & $10.7 \pm 0.03^{\mathrm{a}}(3579)$ \\
\hline Not selected & $2.9 \pm 0.01^{\mathrm{a}}(4868)$ & \\
\hline Maternal Age & & $11.7 \pm 0.19^{\mathrm{b}}(113)$ \\
\hline 2 & $2.9 \pm 0.02^{\mathrm{a}}(145)$ & $11.4 \pm 0.06^{\mathrm{ab}}(1104)$ \\
\hline 3 & $3.0 \pm 0.01^{\mathrm{b}}(1445)$ & $11.2 \pm 0.06^{\mathrm{a}}(976)$ \\
\hline 4 & $3.3 \pm 0.01^{\mathrm{b}}(1286)$ & $11.3 \pm 0.08^{\mathrm{a}}(632)$ \\
\hline 5 & $3.0 \pm 0.01^{\mathrm{b}}(795)$ & $11.4 \pm 0.07^{\mathrm{ab}}(800)$ \\
\hline 6 & $3.0 \pm 0.01^{\mathrm{b}}(1012)$ & $11.3 \pm 0.06^{\mathrm{a}}(929)$ \\
\hline $7+$ & $2.9 \pm 0.01^{\mathrm{b}}(1185)$ & \\
\hline Gender & & $11.5 \pm 0.04^{\mathrm{b}}(2359)$ \\
\hline Male & $3.0 \pm 0.01^{\mathrm{b}}(3006)$ & $11.1 \pm 0.04^{\mathrm{a}}(2195)$ \\
\hline Female & $2.9 \pm 0.02^{\mathrm{a}}(2862)$ & $11.3 \pm 0.03(4553)$ \\
\hline Birth type & & $10.8 \pm 0.05^{\mathrm{ab}}(1944)$ \\
\hline Single & $3.0 \pm 0.01^{\mathrm{b}}(4371)$ & \\
\hline Twin & $2.9 \pm 0.01^{\mathrm{b}}(1494)$ & $0.35^{\mathrm{a}}(2)$ \\
\hline Triplet & $2.7 \pm 0.06^{\mathrm{a}}(3)$ &
\end{tabular}

Note: Different letters as superscripts in the same column indicate a difference at the $5 \%$ significance level.

Table 7. Variation of $2016-2020$ lactation milk yields $(\bar{x} \pm S \bar{x})$ in the elite herds according to age and farms

\begin{tabular}{|c|c|c|c|c|c|}
\hline & 2016 & 2017 & 2018 & 2019 & 2020 \\
\hline \multicolumn{6}{|c|}{ Variation by farms } \\
\hline 1 & $146,7 \pm 5,19^{a}(78)$ & $163,5 \pm 9,51^{a}(100)$ & $290,4 \pm 6,86^{\text {bc }}(95)$ & $312,8 \pm 4,83^{c d}(144)$ & $337,5 \pm 3,54^{\text {cd }}(156)$ \\
\hline 2 & $149,3 \pm 4,97^{a}(80)$ & $266,1 \pm 6,12^{c}(77)$ & $269,0 \pm 7,92^{\mathrm{a}}(72)$ & $277,1 \pm 5,36^{b}(78)$ & $347,4 \pm 4,00^{\text {cde }}(86)$ \\
\hline 3 & $153,3 \pm 3,38^{a}(103)$ & $193,1 \pm 7,61^{b}(81)$ & $300,8 \pm 6,82^{\mathrm{cd}}(94)$ & $259,8 \pm 5,21^{a}(104)$ & $349,8 \pm 4,07^{\text {de }}(116)$ \\
\hline 4 & $156,7 \pm 6,40^{\mathrm{ab}}(53)$ & $213,8 \pm 4,60^{b}(62)$ & $270,7 \pm 6,05^{\mathrm{ab}}(75)$ & $302,8 \pm 7,36^{c}(72)$ & $334,3 \pm 5,80^{\mathrm{bc}}(81)$ \\
\hline 5 & $188,5 \pm 8,96^{c}(57)$ & - & $301,3 \pm 6,40^{c d}(90)$ & $345,5 \pm 7,34^{f}(108)$ & $320,9 \pm 4,57^{\mathrm{a}}(117)$ \\
\hline 6 & $172,0 \pm 3,99^{b}(92)$ & $347,3 \pm 5,20^{d}(120)$ & $275,9 \pm 5,21^{\mathrm{ab}}(120)$ & $258,3 \pm 4,79^{a}(187)$ & $323,6 \pm 4,24^{\mathrm{ab}}(134)$ \\
\hline 7 & $238,9 \pm 6,46^{d}(148)$ & $349,5 \pm 5,79^{d}(146)$ & $397,0 \pm 6,10^{f}(148)$ & $333,7 \pm 4,87^{\mathrm{ef}}(210)$ & $354,2 \pm 3,70^{\mathrm{e}}(219)$ \\
\hline 8 & $189,8 \pm 3,65^{c}(146)$ & $344,3 \pm 4.94^{\mathrm{d}}(167)$ & $296,0 \pm 6,57 c(140)$ & $330,0 \pm 5,30^{\text {def }}(168)$ & $374,1 \pm 3,48^{f}(178)$ \\
\hline 9 & $148,4 \pm 4,77^{a}(74)$ & $417,0 \pm 10,71^{\mathrm{e}}(53)$ & $341,7 \pm 6,10^{\mathrm{e}}(117)$ & $333,4 \pm 5,81^{\mathrm{ef}}(119)$ & $371,2 \pm 5,22^{f}(128)$ \\
\hline 10 & $148,8 \pm 4,85^{a}(83)$ & $400,2 \pm 12,68^{e}(48)$ & $318,2 \pm 5,18^{d}(195)$ & $315,8 \pm 7,81^{\text {cde }}(66)$ & $315,7 \pm 5,02^{a}(74)$ \\
\hline \multicolumn{6}{|c|}{ Variation by ages } \\
\hline 2 & $172,9 \pm 4,28(244)$ & $298,8 \pm 9,26^{\mathrm{ab}}(167)$ & $301,0 \pm 5,45^{a}(226)$ & $314,3 \pm 4,32^{b}(266)$ & $319,4 \pm 5,93^{a}(48)$ \\
\hline 3 & $174,6 \pm 4,42(158)$ & $300,7 \pm 7,15^{\mathrm{ab}}(186)$ & $309,9 \pm 3,46^{\mathrm{ab}}(517)$ & $315,2 \pm 4,69^{b}(209)$ & $341,0 \pm 2,98^{b}(294)$ \\
\hline 4 & $172,6 \pm 3,04(347)$ & $322,6 \pm 8,63^{b}(139)$ & $342,2 \pm 5,74^{\mathrm{b}}(139)$ & $309,3 \pm 3,49^{b}(395)$ & $348,2 \pm 3,40^{b}(230)$ \\
\hline 5 & $190,3 \pm 6,05(74)$ & $293,7 \pm 6,10^{\mathrm{ab}}(280)$ & $338,4 \pm 9,85^{b}(280)$ & $326,0 \pm 5,24^{b c}(180)$ & $348,3 \pm 4,44^{b}(163)$ \\
\hline 6 & $148,2 \pm 2,71(2)$ & $308,4 \pm 14,05^{\mathrm{ab}}(51)$ & $311,2 \pm 5,95^{\mathrm{ab}}(51)$ & $340,7 \pm 15,18^{c}(23)$ & $347,3 \pm 2,95^{b}(314)$ \\
\hline $7+$ & $184,6 \pm 7,51(89)$ & $301,2 \pm 21,79^{a}(31)$ & $314,6 \pm 12,57^{\mathrm{ab}}(11)$ & $310,8 \pm 5,40^{\mathrm{a}}(121)$ & $352,48 \pm 3,39^{b}(240)$ \\
\hline \multicolumn{6}{|c|}{ Total } \\
\hline & $175,6 \pm 2,00(914)$ & $301,2 \pm 3,61(854)$ & $316,5 \pm 2,36(1204)$ & $310,8 \pm 2,02(1194)$ & $346,1 \pm 1,46$ (1289) \\
\hline
\end{tabular}


under the semi-intensive conditions are exposed from year to year have an effect on this increase, the selection program applied also has an effect.

The lactation milk yield values calculated from the project goats showed similarities with the previous studies for some years and differences for some years. Lactation milk yield in Kilis goats was reported as 294 liters by Baltacı (1990), as 376 liters by Keskin (2000), as 213 liters by Aktepe (2009), as 294 liters by Gül et al. (2016 and 2020), as 316-376 liters by Keskin et al. (2017).

The values reported in the literature are similar to the values of the herds seen in Table 7 . These similarities or differences may be due to year or herd differences, management or feeding differences applied to the herds, and the change in age distribution of the animals at each herds.

\section{Conclusion}

The results of the works and processes carried out in this project so far can be listed as follows;

Breeders have learned record keeping and its importance. In the second five years of the project, it was observed that the breeders had experience in these matters.

With the effect of the seminars given to the goat breeders, important developments have been achieved especially in the field of health protection and parasite control. It is observed that many breeders are more interested in vaccination.

Breeders have started to provide breeding stock from animals whose yield characteristics have been determined.

Animal sales were made from project animals to different regions of Turkiye (such as Doğanhisar district of Konya province, Adana, Diyarbakır). The animals taken to these provinces were visited by the project team and it was observed that they adapted to the new regions. In order to demonstrate this relevance with objective criteria, a project was prepared and submitted to TAGEM for the evaluation of herds of similar ages in Konya and Kilis provinces. Unfortunately, the project was not supported. Despite this, the project team went to Doğanhisar and met with the breeders who distributed Kilis goats, and the breeders stated that they were satisfied with these goats.

The mating records kept in the elite herds included in the project were checked by paternity test. For this purpose, 118 heads of kids and 19 their possible fathers randomly selected from the elite herd were evaluated with financial support provided by Hatay Mustafa Kemal University Scientific Research Projects Commission. As a result of the analysis, 3.4\% error was detected in the pairing of father and kid. According to the five different herds, the mismatch between father and kid was $0.0 \%, 0 \%$, $3.0 \%, 4.8 \%$ and $7.4 \%$ in the herds (Keskin et al., 2017). Obtained results show that elite herd breeders are successful in hand mating.

Scientific data obtained from Kilis goats were shared nationally and internationally, contributing to the promotion of the project. In addition, the best kid and lamb competition was held in Kilis and the project was introduced on a local basis.

As conclusion, it is seen that lactation milk yield increases year by year in the elite herds. There is also a wide variation for calculated lactation milk yield in the elite herds. For the more effective use of this situation in breeding, it would be beneficial to establish Kilis Goat Research Institute in Kilis. And, it would be beneficial to produce semen from pedigree males in this special herd to be created here and use them for artificial insemination in our country.

On this occasion, I would like to reiterate that, if this institute is established, very rapid developments can be achieved in goat breeding with semen to be produced from high quality and tested bucks in our country. And, Turkiye can create a brand in this field in the international arena.

\section{Acknowledgments}

This manuscript has been prepared as part of a project titled as "National Genetic Improvement Project for Kilis Goats at Breeders' Condition" carried out in cooperation with Republic Of Turkiye Ministry Of Agriculture and Forestry, General Directorate of Agricultural Research and Policies. The authors would like to thank the General Directorate and Kilis sheep and goat breeders' association.

\section{Author contributions}

All authors contributed equally to the study.

\section{Conflicts of interest}

The author declare no conflicts of interest.

\section{References}

Aktepe, T. (2009). Kilis keçilerinde anatomik morfolojik ve fizyolojik adaptasyon parametrelerinin saptanması üzerine bir araştırma. Yüksek lisans tezi. Çukurova Üniversitesi Fen Bilimleri Enstitüsü Zootekni Anabilim Dalı, Adana.

Anonymous (1969). Türkiye'nin tarimsal üretim projeksiyonu. Ankara. 
Anonymous (2021). illere ait mevsim normalleri (19912020). https://www.mgm.gov.tr/ veridegerlendirm e/il-ve-ilceler-istatistik.aspx?m=KILIS.

Baltacı, S. (1990). Ceylanpınar Tarım iş̧letmesinde yetiştirilen Kilis keçisi ve melezlerinin adaptasyonu üzerine bir araştırma. Çukurova Üniversitesi Fen Bilimleri Enstitüsü Zootekni Anabilim Dalı Yüksek Lisans Tezi, Adana.

Gül, S., Keskin, M., Göçmez, Z., Gündüz, Z. (2016). Effects of Supplemental Feeding on Performance of Kilis Goats Kept on Pasture Condition. Italian Journal of Animal Science. 15 (1): 110-115.

Gül, S., Yılmaz, O., Gündüz, Z., Keskin, M., Cemal, İ., Ata, N., Önel, S.E. (2020). The genetic structure of the goat breeds belonging to Northwest part of Fertile Crescent. Small Ruminant Research, 182: 22-28.

Güney, O. (1984). Saanen x Kilis ve Saanen x Kıl birinci geriye melez erkek oğlakların besi gücü ve karkas özellikleri üzerinde bir araştırma. Doğa Bilim Dergisi, Seri D1, 8 (1).

Keskin. M., Kaya, Ş., Özcan, L. ve Biçer, O. (1996). Hatay Bölgesinde yetiştirilen keçilerin bazı morfolojik ve fizyolojik özellikleri üzerinde bir araştırma. Mustafa Kemal Üniversitesi Ziraat Fakültesi Dergisi, 1(1): 6984.

Keskin, M. (2000). Hatay bölgesinde yoğun yetiştirme koşullarinda Damascus keçilerinin morfolojik özellikleri ve performanslarinin saptanması. Mustafa Kemal Üniversitesi Fen Bilimleri Enstitüsü, Zootekni Anabilim Dalı, Doktora Tezi, Antakya.

Keskin, M., Gül, S., Biçer, O., Daşkıran, İ. (2017). Some reproductive, lactation, and kid growth characteristics of Kilis goats under semiintensive conditions. Turk J Vet Anim Sci., 41: 248-254.
Keskin, M., Yılmaz, O., Gündüz, Z., Ata, N., Gül, S., Cemal, ì., Karaca, O., Önel, S.E. (2019). Microsatellite panels for parentage testing of Kilis goats reared in Turkey. Turk J Vet Anim Sci., 43: 94-101.

Keskin, M. (2020). Effects of nutritional practices in different periods on some yield characteristics of Kilis goats. Mustafa Kemal University Journal of Agricultural Sciences 25 (2): 122-126.

Özcan, L. (1977). Ç.Ü. Ziraat Fakültesinde yetiştirilen Kilis ve Kılkeçilerinin ıslahında Saanen ve G1 genotiplerinden yararlanma olanakları. Çukurova Üniversitesi Ziraat Fakültesi Yayınları, 122, Bilimsel Inceleme ve Araştırma Tezleri: 19, Adana.

Özcan, L., Pekel, E., Güney, O. (1974). Ç.Ü. Ziraat Fakültesinde yetiştirilen Kilis, Kıl, Gs1 keçilerinde döl ve süt verim özellikleri üzerine karşilaştirmali araştirmalar. Çukurova Üniversitesi Ziraat Fakültesi Yıllı̆̆ı, 5: 1-3 Ankara.

Sönmez, R. (1974). Melezleme yoluyla yerli Kılkeçilerin süt keçisine çevrilme olanakları. Ege Üniversitesi Ziraat Fakültesi Yayınları no: 326, İzmir.

Sönmez, R., Şengonca, M., Kaymakçı, M. (1973). Ege Bölgesinde yetiştirilen çeşitli süt tipi keçilerle bunlarin melezlerinin adaptasyon durumu ve verim özellikleri üzerine mukayeseli bir araştirma. IV. Bilim Kongresi, Ankara.

Şimşek, U.G., Bayraktar, M., Gürses, M. (2006). Çiftlik koşullarında kıl keçilerine ait bazı verim özelliklerinin araştırılması. Fırat Üniversitesi Sağıı Bilimleri Veteriner Dergisi, 20 (3): 221-227. 